\title{
Ciśnieniowe próby szczelności gazociągów z tworzyw sztucznych o MOP 1,6 MPa
}

\begin{abstract}
W artykule omówiono odkształcenia, jakim podlegają rury z materiałów o właściwościach lepkosprężystych pod wpływem ciśnienia wewnętrznego, w tym podczas ciśnieniowych prób szczelności. Omówiono wybraną procedurę prowadzenia próby szczelności oraz przedstawiono wyniki jej realizacji na przykładzie rur z poliamidu PA 12 o MOP 1,6 MPa.
\end{abstract}

Słowa kluczowe: gazociąg, próba ciśnieniowa, rury z poliamidu PA 12.

\section{Pressure testing of plastic gas pipelines with a MOP of $1.6 \mathrm{MPa}$}

The article discusses the deformations to which pipes with viscoelastic materials proporties are subjected to under the influence of internal pressure, including during pressure tightness tests. The selected procedure for conducting the leak test was discussed and the results of its implementation on the example of polyamide PA12 pipes with MOP 1.6 MPa were presented.

Key words: gas pipeline, pressure testing, polyamide PA 12 pipes.

\section{Wprowadzenie}

Gazociągi przed oddaniem do użytkowania należy poddać próbie wytrzymałości i szczelności [13]. Podczas prowadzenia prób ciśnieniowych gazociągów z materiałów polimerowych o maksymalnym ciśnieniu roboczym MOP 1,6 MPa konieczne jest odmienne podejście od stosowanego w przypadku gazociągów stalowych $[5,7]$, co wynika z właściwości lepkosprężystych tych materiałów. Rury z tworzyw termoplastycznych, takich jak np. poliamid, zaliczane są do grupy rur elastycznych i podczas badań szczelności rurociągów z nich wybudowanych będą one zwiększać swoją objętość [1].

W rurach z tworzyw termoplastycznych pełzanie materiału i relaksacja naprężeń jest znacznie większa niż w rurach z materiałów tradycyjnych, np. stalowych czy żeliwnych [2]. Po przyłożeniu stałego obciążenia wraz z upływem czasu wzrasta odkształcenie materiału, co spowodowane jest zjawiskiem pełzania. Jeżeli pod wpływem ciśnienia rura z tworzywa termoplastycznego odkształci się, a odkształcenie będzie utrzymywało się na stałym poziomie, wówczas poziom naprężeń w ściance rury będzie malał - zjawisko to nazywane jest relaksacją naprężeń [2]. Pod wpływem ciśnienia wewnętrznego $\mathrm{w}$ ściance rury $\mathrm{z}$ tworzywa termoplastycznego powstają na- prężenia obwodowe, które powodują odkształcenie się rury, będące sumą trzech składowych [3]:

$$
\varepsilon=\varepsilon_{1}+\varepsilon_{2}+\varepsilon_{3}
$$

gdzie:

$\varepsilon_{1}$ - odkształcenie sprężyste (natychmiastowe),

$\varepsilon_{2}$ - odkształcenie wysokoelastyczne,

$\varepsilon_{3}$ - odkształcenie trwałe (plastyczne).

Rury z materiałów polimerowych poddane działaniu naprężeń pochodzących od ciśnienia wewnętrznego będą ulegały głównie odkształceniom sprężystym $\varepsilon_{1}$ i wysokoelastycznym $\varepsilon_{2}$ [2]. Odkształcenia trwałe $\varepsilon_{3}$ (najmniejsze) występują po długotrwałym obciążeniu rury. Po obciążeniu rurociągu ciśnieniem wewnętrznym wystąpi natychmiastowe odkształcenie sprężyste materiału i postępujące w czasie odkształcenie wysokoelastyczne oraz odkształcenie trwałe (plastyczne) [8]. Dla krótkich okresów trwania próby szczelności, nawet przy zwiększonym ciśnieniu w porównaniu z warunkami eksploatacyjnymi, wartość odkształcenia trwałego będzie bliska zeru. Podczas prób szczelności wystąpią więc głównie odkształcenia sprężyste i wysokoelastyczne. 
Różne tworzywa polimerowe mogą mieć różny poziom tych odkształceń występujących w określonym czasie, co może wpływać na ustalenie warunków prowadzenia prób szczelności.

\section{Metody prowadzenia prób ciśnieniowych według PN-EN 12327:2013}

Metody prowadzenia prób ciśnieniowych gazociągów opisane w normie PN-EN 12327:2013 [11] mogą być stosowane przy próbach wytrzymałości, szczelności i próbach łączonych. W normie nie podano poziomów ciśnień prób, ich czasów trwania oraz kryteriów akceptacji. Wskazano natomiast, że ciśnienie próby wytrzymałości lub próby łączonej powinno być co najmniej równe lub wyższe od maksymalnego ciśnienia przypadkowego (MIP) systemu. Szczegółowa procedura prowadzenia próby szczelności powinna być opracowana przez operatora gazociągu lub kompetentny organ i winna precyzować między innymi: metodę przeprowadzania próby, ciśnienie próby, czynnik próby oraz kryteria odbioru.

Metoda przeprowadzania próby oraz zastosowane ciśnienie powinny być dobrane $\mathrm{z}$ uwzględnieniem wykorzystanych materiałów, typów połączeń, zamierzonego zastosowania i norm funkcjonalnych dla systemów dostaw gazu. W zakresie norm obejmujących wymagania funkcjonalne dla gazociągów z polietylenu można się odnieść do normy PN-EN 12007-2:2013 [11]. Dla gazociągów z tworzyw sztucznych o MOP 1,6 MPa nie ma polskiej normy określającej zalecenia funkcjonalne. Istnieje więc potrzeba ustalenia odpowiedniej metody próby oraz warunków jej realizacji. W tym zakresie można skorzystać z metod wymienionych w normie PN-EN 12327:2013 [11], w której zwrócono uwagę, że w przypadku rurociągów z tworzyw sztucznych zaleca się uwzględnienie efektu pełzania materiału podczas utrzymywania rury pod zwiększonym ciśnieniem, przy czym maksymalne dopuszczalne odchylenie (zmiana) ciśnienia/objętości będzie zależa- ło od rodzaju materiału, poziomu ciśnienia, średnicy i lokalizacji badanego odcinka rurociągu.

Norma opisuje pneumatyczne i hydrostatyczne metody prowadzenia prób ciśnieniowych. Ze względu na stosunkowo wysokie ciśnienie próby, które powinno być większe od maksymalnego ciśnienia roboczego, w tym przypadku od 1,6 MPa, oraz bezpieczeństwo wskazane jest zastosowanie próby hydrostatycznej.

Jedną $\mathrm{z}$ metod wymienionych $\mathrm{w}$ normie PN-EN 12327:2013 [11], która może być realizowana przy próbie hydrostatycznej, jest metoda pomiaru i rejestracji ciśnienia.

Po osiągnięciu określonego ciśnienia próbnego odcinek poddany próbie oddziela się od źródła ciśnienia i po stabilizacji warunków rozpoczyna się rejestrację ciśnienia lub odczytuje się ciśnienie na początku i na końcu próby. Ponieważ opisane w normie [11] metody nie określają szczegółowych warunków prowadzenia prób ciśnieniowych, konieczne jest wzorowanie się na procedurach istniejących lub opracowanie nowych.

Jedną z metod, która uwzględnia właściwości lepkosprężyste rur jest metoda opisana w punkcie A.27 normy PN-EN 805:2002 [12]. Dotyczy ona co prawda badania szczelności w systemach transportujących wodę, jednak ze względu na to, że maksymalne ciśnienie wodociągu z polietylenu może wynosić 16 bar, a próby szczelności według opisanej metody mogą być realizowane na poziomie wartości iloczynu współczynnika 1,5 i maksymalnego ciśnienia projektowego, można rozważyć możliwość jej zastosowania do sprawdzania szczelności gazociągów z tworzyw sztucznych o MOP 1,6 MPa.

\section{Metoda hydrostatyczna próby szczelności według PN-EN 805:2002 [12]}

Cała próba szczelności składa się z próby wstępnej, obejmującej okres relaksacji naprężeń rury elastycznej ze zintegrowanej próby spadku ciśnienia, i z próby głównej. Przykładowy przebieg zmian ciśnienia w czasie próby przedstawiono na rysunku 1.

Celem próby wstępnej jest ustalenie warunków początkowych dotyczących zmian objętości rurociągu w zależności od ciśnienia, czasu i temperatury.

W trakcie próby wstępnej po odpowietrzeniu rurociągu zwiększa się ciśnienie w sposób ciągły do wartości ciśnienia próby i utrzymuje przez okres 30 minut przez pompowanie - ciągłe lub z krótkimi przerwami. W tym czasie przeprowadza się kontrolę wizualną w celu stwierdzenia ewentualnych przecieków. Następnie pozostawia się rurociąg pod ci- śnieniem na 1 godzinę bez dopompowywania wody. Rurociąg może się odkształcać wskutek pełzania lepkosprężystego, co będzie powodowało spadek ciśnienia. Stabilizacja ciśnienia oznaczać będzie zatrzymanie zjawiska pełzania materiału rury. Jeżeli po godzinie wartość ciśnienia obniży się o więcej niż 30\% ciśnienia próby, przerywa się próbę wstępną i obniża ciśnienie do ciśnienia atmosferycznego w celu analizy warunków (np. wpływu temperatury).

Jeżeli próba wstępna zakończy się pozytywnie, wówczas przeprowadzana jest zintegrowana próba spadku ciśnienia, której główny cel stanowi przerwanie pełzania materiału rury spowodowanego naprężeniami wywołanymi przez ciśnienie próby. Gwałtowne zmniejszenie ciśnienia w czasie jej trwania powoduje skurcz rury, który będzie prowadził do wzrostu 
ciśnienia. Na tym etapie próby istnieje również możliwość oceny, czy objętość pozostałego powietrza w rurociągu jest na tyle mała, że można rozpocząć próbę główną. Aby to sprawdzić, obniża się szybko ciśnienie, odprowadzając z badanego rurociągu wodę do momentu osiągnięcia $\Delta p$ równego od $10 \%$ do 15\% wartości ciśnienia próby. Objętość usuniętej wody $\Delta V$ nie powinna być większa niż wartość $\Delta V_{\max }$ obliczona z zależności (2).

$$
\Delta V_{\text {max }}=1,2 \cdot V \cdot \Delta p\left(\frac{1}{E_{w}}+\frac{D}{e \cdot E_{R}}\right)
$$

gdzie:

$\Delta V_{\max }$ - dopuszczalny ubytek wody $\left[\mathrm{dm}^{3}\right]$;

$V$ - objętość badanego odcinka rurociągu $\left[\mathrm{dm}^{3}\right]$;

$\Delta p$ - zmierzony spadek ciśnienia $[\mathrm{kPa}]$;

$E_{w}$ - współczynnik sprężystości objętościowej wody $[\mathrm{kPa}]$;

$D$ - wewnętrzna średnica rury [m];

$e-$ grubość ścianki rury [m];

$E_{R}-$ moduł sprężystości ścianki rury w kierunku obwodowym $[\mathrm{kPa}]$;

1,2- współczynnik korekcyjny (np. ze względu na zawartość powietrza) w czasie przeprowadzania głównej próby ciśnieniowej.

Jeżeli $\Delta V$ jest większe niż $\Delta V_{\max }$, przerywa się procedurę próby i ponownie odpowietrza rurociąg. W przypadku spełnienia warunku
$\Delta V \leq \Delta V_{\max }$ przystępuje się do próby głównej. Jeżeli w czasie 30 minut próby głównej będzie obserwowany wzrost krzywej rejestrowanego ciśnienia, wówczas próbę uznaje się za udaną. Jeżeli w czasie tego okresu nachylenie krzywej ciśnienia będzie malało, świadczy to o przecieku. W przypadkach wątpliwych próbę główną można wydłużyć do 90 minut. Wówczas dopuszczalny spadek ciśnienia od wartości maksymalnej, jaka wystąpiła w czasie skurczu rury, może wynosić $25 \mathrm{kPa}$. Jeżeli spadek ciśnienia jest większy niż $25 \mathrm{kPa}$, wynik próby uznaje się za negatywny.

Po zlokalizowaniu i usunięciu nieszczelności ponowne wykonanie próby głównej jest możliwe pod warunkiem przeprowadzenia uprzednio próby wstępnej i próby zintegrowanego spadku ciśnienia.



Rys. 1. Przykładowy przebieg zmian ciśnienia w czasie próby szczelności na podstawie PN-EN 805:2002 [13]

\section{Weryfikacja metody hydrostatycznej próby szczelności według PN-EN 805:2002 na przykładzie rur z poliamidu PA 12}

W ramach realizowanej w INiG - PIB pracy pt. Weryfikacja dostępnych procedur prowadzenia prób szczelności rurociagów z tworzyw sztucznych o $M O P=1,6 \mathrm{MPa}$ przeprowadzono badania modelowe próbek rur i ich połączeń wykonanych z poliamidu PA 12. Materiał ten różni się zasadniczo od poliamidu stosowanego do budowy gazociągów w latach 90. ubiegłego wieku. Do podstawowych jego zalet należy zaliczyć możliwość łączenia zarówno przez zgrzewanie doczołowe, jak i elektrooporowe. Rury z PA 12 mogą być układane w gruncie technikami tradycyjnymi oraz technikami bezwykopowymi, dzięki którym skraca się czas budowy oraz zmniejsza ingerencję w środowisko. W zakresie stosowania rur PA 12 do budowy gazociągów, np. na terenach szkód górniczych, należałoby ocenić ich odporność na dodatkowe obciążenia, szeroko opisane w artykule [9].

Badania modelowe, których celem było zweryfikowanie dostępnych procedur prowadzenia prób ciśnieniowych, przepro- wadzono na próbkach o wymiarach $d_{n} 110 \mathrm{i} d_{n} 160 \mathrm{~mm}$ w szeregu wymiarowym SDR 11. Oprócz rur do badań wytypowano także podstawowe elementy systemu, takie jak: kształtki elektrooporowe oraz przejścia PA/STAL. Połączono je z zastosowaniem technologii zgrzewania doczołowego i elektrooporowego. Przygotowane próbki do badań przedstawia fotografia 1 . Badania przeprowadzono w warunkach laboratoryjnych, utrzymując temperaturę otoczenia na poziomie $23 \pm 2^{\circ} \mathrm{C}$. Przed hydrostatyczną próbą szczelności wykonano próbę pneumatyczną przy ciśnieniu 0,5 bar w celu wykrycia ewentualnych nieszczelności. Szczelność połączeń sprawdzono środkiem pianotwórczym i nie zaobserwowano żadnych nieszczelności, po czym próbki rozhermetyzowano i napełniono wodą. Odpowietrzone próbki pozostawiono na 24 godziny w celu wyrównania się temperatury wody, rury i otoczenia. Po tym czasie przystąpiono do wykonania prób. Próby przeprowadzono przy ciśnieniu 1,5 $\times$ MOP, tj. 24 bar. Dodatkowo w stosunku do procedury 
opisanej w PN-EN 805:2002 [12], w celu obserwacji odkształceń rury pod wpływem zmian ciśnienia, wykonywano pomiary średnicy rury w trzech punktach. Zmiany średnicy w charakterystycznych punktach próby zobrazowano na rysunku 2. Próby szczelności zrealizowano zgodnie z procedurą opisaną w normie [12]. Zarówno próba szczelności rury $d_{n} 160$, jak i $d_{n} 110$ zakończyły się wynikiem negatywnym, mimo że nie zaobserwowano żadnych nieszczelności. Ponadto próbki zostały prawidłowo odpowietrzone, co potwierdziły pomiary objętości upuszczonej wody $\Delta V$ podczas zintegrowanej próby spadku ciśnienia, które nie przekraczały obliczonej wartości dopuszczalnej $\Delta V_{\max }$. Czynnikiem, który mógł mieć wpływ na zaobserwowany spadek ciśnienia w czasie trwania próby głównej, była temperatura. Podczas realizowanych prób szczelności nie zaobserwowano jednak jej zmiany, która mogłaby powodować obniżenie ciśnienia. W takim przypadku, ze względu na właściwości lepkosprężyste materiału rur, analizie poddano wyniki pomiarów zmiany średnicy zewnętrznej. Opisana w punkcie A.27 normy [12] procedura próby szczelności przeznaczona jest do stosowania dla rur o właściwościach lepkosprężystych i uwzględnia występujące zjawisko pełzania materiału, które może wpływać na wyniki prób ciśnieniowych. Efekt ten może być znaczący w przypadku prób z zastosowaniem wyższych ciśnień [4]. Podczas próby wstępnej próbka utrzymywana była przez czas 30 minut pod określonym ciśnieniem próby przez cykliczne dopompowywanie wody, które jest wymagane ze względu na pełzanie materiału (odkształcenia wysokoelastyczne). W tym czasie próbki zwiększały swoją średnicę. W kolejnym etapie próby wstępnej, tj. przez 60 minut, nie dopompowywano wody do próbek i nastąpił spadek ciśnienia, któremu powinno towarzyszyć w dalszym ciągu postępujące odkształcanie się rur. W tym czasie wystąpiło zwiększenie średnicy rury $d_{n} 160$ o $0,1 \mathrm{~mm}$ (rysunek 2). W kolejnym etapie próby ciśnienie $\mathrm{w}$ badanych próbkach zostało obniżone poprzez upuszczenie wody. Pełzanie materiału wywołane naprężeniami pochodzącymi od ciśnienia wewnętrznego powinno zostać przerwane, a nagły spadek ciśnienia wewnętrznego - prowadzić do „kurczenia” się rury, w wyniku czego powinno wzrosnąć ciśnienie, co zaobserwowano podczas realizowanych prób. Na tym etapie zaobserwowany został również wymagany skurcz rury - zmniejszenie średnicy zewnętrznej rur (rysunek 2 pkt $\mathrm{p}_{5}$ ). Podczas dalszego przebiegu próby w czasie $30 \mathrm{~min}$ powinien być obserwowalny wzrost ciśnienia w wyniku dalej postępującego skurczu rury. Zarówno w przypadku pierwszej, jak i drugiej próbki początkowo, po około 15 minutach, nastąpił wzrost ciśnienia o wartość 0,1 bar, po czym na koniec tego etapu ciśnienie spadło o 0,1 bar. W tym czasie dla rury $d_{n} 160$ w jednym z punktów pomiarowych wykazano w czasie pierwszych 15 minut zmniejszenie się średnicy o $0,1 \mathrm{~mm}$, a w kolejnych 15 minutach nie stwierdzono już zmiany. Ze względu na brak wymaganego wzrostu ciśnienia próbę, zgodnie z procedurą, wydłużono o 60 minut. Na koniec tego czasu ciśnienie nie powinno być mniejsze o więcej niż $25 \mathrm{kPa}$ (0,25 bar) od największej wartości ciśnienia podczas próby głównej (wystąpienia skurczu rury).

W obu przypadkach odnotowano spadek ciśnienia o 0,5 bar i zaobserwowano niewielki wzrost wartości średnicy, tj. o około $0,05 \mathrm{~mm}$.

Uzyskane wyniki mogą świadczyć o tym, że w początkowej fazie próby głównej, tj. w ciągu pierwszych 15 minut, ciśnienie w próbkach wzrastało w wyniku skurczu obwodowego rur, po czym zjawisko to zostało zatrzymane i nastąpiło ponownie pełzanie materiału rur, któremu towarzyszył spadek ciśnienia o wartość większą niż dopuszczalna wartość wynikająca z ustalonych kryteriów w normie [12].

Sytuacja taka mogła wynikać z tego, że rury z poliamidu PA 12 charakteryzują się większą w stosunku np. do polietylenu wartością modułu Younga [6], tj. modułu odkształcalności liniowej, nazywanego również modułem sprężystości liniowej, od którego zależy sztywność obwodowa rury. Podobne zjawisko może zachodzić w przypadku wzmacnianych rur polietylenowych, które charakteryzują się większą sztywnością obwodową oraz mniejszym współczynnikiem rozszerzalności liniowej [3].

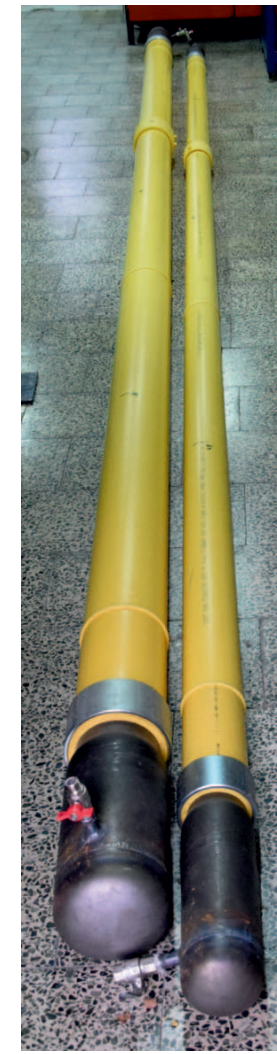

Fot. 1. Próbki przygotowane do badań modelowych Można więc przypuszczać, że czas, który został zastosowany podczas próby wstępnej i przez który próbki utrzymywano pod ciśnieniem próby przez dopompowywanie wody, był zbyt krótki i nie nastąpiło wystarczające odkształcenie rur, które pozwo-

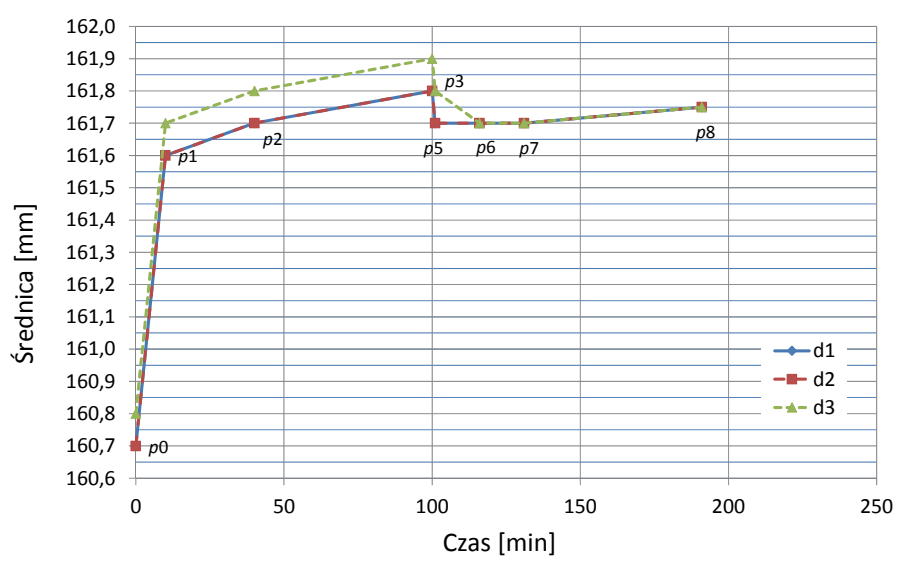

Rys. 2. Zmiana średnicy rury $d_{n} 160 \mathrm{z}$ PA-U 12 w czasie trwania próby szczelności 
liłoby w kolejnych etapach próby na powstanie odpowiedniego skurczu i w efekcie wzrostu ciśnienia próby.

Poddana weryfikacji metoda badania szczelności wymaga modyfikacji parametrów w celu ich dostosowania do właściwości rur z poliamidu PA 12. Wydłużenie czasu trwania próby wstępnej powinno powodować większe odkształcenie się rury, które w dalszej części próby spowoduje wystąpienie właściwego skurczu i zatrzymanie zjawiska pełzania materiału rury, będącego warunkiem uzyskania pozytywnego wyniku próby według ustalonych kryteriów. Jeżeli wydłużenie czasu próby wstępnej okaże się niewystarczające, może być ko- nieczne rozważenie opracowania nowych kryteriów akceptacji próby. Określenie nowych warunków próby wymagać będzie przeprowadzenia szeregu badań i analiz, a w przypadku ustalenia nowego kryterium akceptacji wyników próby zalecane byłoby ich zweryfikowanie w warunkach terenowych.

Na podstawie uzyskanych wyników badań modelowych można wnioskować, że dopuszczenie do budowy gazociągów o MOP 1,6 MPa różnych tworzyw sztucznych oraz rur o różnej konstrukcji, np. rur wzmacnianych, może wymagać określenia odrębnych parametrów lub opracowania nawet specjalnych procedur prowadzenia prób szczelności.

\section{Wnioski}

1. Badania modelowe wykazały, że w celu przeprowadzenia prób szczelności gazociągów z poliamidu PA $12 \mathrm{wg}$ procedury opisanej w punkcie A.27 normy PN-EN 805:2002 [12], która uwzględnia właściwości lepkosprężyste, wymagane jest ustalenie odpowiednich parametrów próby ciśnieniowej dla tego tworzywa.

2. Ze względu na większą niż w przypadku PE wartość modułu Younga czas trwania próby wstępnej powinien zostać wydłużony tak, aby uzyskać odpowiednie odkształcenie rury, które pozwoliłoby na wystąpienie właściwego skurczu, umożliwiającego zatrzymanie zjawiska pełzania materiału rury.

3. Jeżeli wydłużenie czasu próby wstępnej okaże się niewystarczające, konieczne może być rozważenie opracowania nowych kryteriów akceptacji próby.

4. Budowa gazociągów o MOP 1,6 MPa z różnych tworzyw sztucznych oraz z rur o różnej konstrukcji może wymagać określenia odrębnych parametrów lub nawet opracowania specjalnych procedur prowadzenia prób szczelności.

Prosimy cytować jako: Nafta-Gaz 2018, nr 5, s. 386-390, DOI: 10.18668/NG.2018.05.06

Artykuł nadesłano do Redakcji 4.12.2017 r. Zatwierdzono do druku 20.03.2018 r.

Artykuł powstał na podstawie pracy statutowej pt. Weryfikacja dostępnych procedur prowadzenia prób szczelności rurociagów z tworzyw sztucznych o $M O P=1,6 \mathrm{MPa}$ - praca INiG - PIB na zlecenie MNiSW; nr zlecenia 0114/GP/17, nr archiwalny DK-4100-115/17.

\section{Literatura}

[1] Bolt A., Suligowski Z.: Próby szczelności rurociagów ciśnieniowych z tworzyw polimerowych. Instal 2007, nr 7-8, s. 70.

[2] Janson L.-E.: Plastics pipes for water supply and sewage disposal. Borealis, Sven Axelsson AB/Affisch \& Reklamtryck AB, Boras 1996, s. 29, 33, 59.

[3] Klupa A.: Rury z materiałów kompozytowych do przesyłania paliw gazowych. Nafta-Gaz 2010, nr 9, s. 805-809.

[4] Klupa A., Czopek J.J., Wróblewska A.: Problemy realizacji prób ciśnieniowych gazociagów z polietylenu. Nafta-Gaz 2007, nr 5, s. 341-346.

[5] Kopczyński A.: Próby specjalne. Wymagania w zakresie wykonania. Nowoczesne Gazownictwo 2002, nr 3, s. 15-21.

[6] Mason J.F., Ponda A., Stanley M., Demicoli D.: Case Study: Engineered Polyamide 12 (PA12) Pipeline Liner for Management of Sour Gas Corrosion at Elevated Temperatures. NACE Conference Papier 2017-9552.

[7] Pusz A.: Kiedy polietylen opanuje wysokie ciśnienie? Przegląd Gazowniczy 2015, vol. 47, nr 3, s. 18-19.

[8] Szewczyk P.: Stabilizacja ciśnienia i temperatury czynnika próby przed rozpoczęciem badania szczelności gazociagów polietylenowych. Nafta-Gaz 2014, nr 5, s. 307-312.

[9] Wróblewska A.: Wplyw parametrów zgrzewania na jakość potączeń gazociagów polietylenowych zlokalizowanych na terenie szkód górniczych. Nafta-Gaz 2015, nr 10, s. 768-775. DOI: 10.18668/NG2015.10.08.

\section{Akty prawne i normatywne}

[10] PN-EN 12007-2:2013 Infrastruktura gazowa-Rurociagi o maksymalnym ciśnieniu roboczym do 16 bar włacznie - Część 2: Szczegółowe wymagania funkcjonalne dotyczące polietylenu (MOP do 10 bar włacznie).

[11] PN-EN 12327:2013 Infrastruktura gazowa - Próby ciśnieniowe, procedury uruchamiania i unieruchamiania - Wymagania funkcjonalne.

[12] PN-EN 8052002 Zaopatrzenie $w$ wodę - Wymagania dotyczace systemów zewnętrznych i ich części składowych.

[13] Rozporządzenie Ministra Gospodarki z dnia 26 kwietnia 2013 r. w sprawie warunków technicznych, jakim powinny odpowiadać sieci gazowe i ich usytuowanie (Dz.U. z 2013 r. poz. 640).

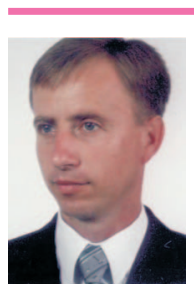

Mgr inż. Piotr SZEWCZYK

Główny specjalista inżynieryjno-techniczny; kierownik Zakładu Przesyłania i Dystrybucji Gazu. Instytut Nafty i Gazu - Państwowy Instytut Badawczy ul. Lubicz 25 A

31-503 Kraków

E-mail: piotr.szewczyk@inig.pl 